\title{
Trends in Foreign Direct Investment and Economic Growth of India with Special Reference to Tamil Nadu
}

\author{
K. Uthayasuriyan
}

\begin{abstract}
Foreign Direct Investments (FDIs) are welcomed by various host countries with multiple objectives such as capital infusion, technological up-gradation and managerial know-how. This measure is carried out at substantial cost of offering various incentives in terms of providing land for industrial investments, supply of uninterrupted power, ensuring problem free labour relation environment etc. These measures are taken by any government on a basis which will have a specific time frame, in order to not let investment become a drain on the economy of the host country. This study intends to evaluate the impact of FDI on the economic growth of India and in the state of Tamil Nadu, the most industrialised and urbanised economy in India. With proactive governance and path breaking policy initiatives and structural reforms, the state has emerged as one of the leading industrialised states of India. The period of this study has been taken for ten years from 2008-09 to 2018-19. The data on the inflow of FDI during this period and the flow of FDI from various source countries have been collected along with the data on various economic parameters pertaining to infrastructure such Gross National Income (GNI), Net National Income (NNI) and Per Capita Net National Income (PCNI). The data collected for the study are entirely the secondary data published by both the state and central governments. The analysed results of the study reveal that the inflow of FDI into India during the study period has been consistent and been growing significantly, as the economy of the country and the dynamic transformation of global economy demanded. This inflow of FDIs has consistently created a positive impact on the economic indicators, making it an essential factor to be very attentively looked after for a sustained growth.
\end{abstract}

\section{Keywords : trends,FDI, labour,Industry.}

\section{INTRODUCTION}

Developing countries, emerging economies, countries such as ours increasingly see foreign direct investment (FDI) as a source of economic development, modernisation and employment generation and have liberalised their FDI regimes to attract investment. The overall benefits of FDI for developing economies are well documented. Based on the host countries policies and level of development, a preponderance of studies show that FDI triggers technology spill over, assists human capital formation, contributes to international trade integration, helps create more competitive business environment and enhances

Revised Manuscript Received on September 25, 2019

Dr. K. Uthayasuriyan, Professor \& Head, Department of International Business, Alagappa University, Karaikudi enterprise development. All these contribute to an impact on the economy of the country. Beyond the initial macro-economic stimulus for actual investment, FDI influences growth by increasing total factor productivity and more generally, the efficiency of resource use in the recipient economy. Technology transfers through FDI generate positive externalities in the host country. FDI provides financial resources for investment in the host country and thereby augments the domestic saving efforts.

\section{RESEARCH PROBLEM}

According to the World Investment Report 2016 of UNCTAD, in the year 2015, global flows of foreign direct investment rose by about 40 percent, to USD1.8 Trillion, the highest level since the global economic and financial crisis began during 2008. However, this growth did not translate into an equivalent expansion in productive capacity in all countries. This is a troubling development in light of the investment needs associated with the newly adopted sustainable development goals and the ambitious action envisaged in the land mark Paris agreement on climate change. Regulations such as the ownership and control of companies are essential in the investment regimes of most countries. But in an era of complex multinational ownership structures, the rationale and effectiveness of this policy on investment needs a comprehensive re-assessment. In a country like India, governments, both the central and state, spread out red carpet to foreign direct investments by offering attractive benefits in terms of allotment of suitable land and providing basic infrastructure like power, water, road etc., and considerable tax benefits to woo them to invest. It goes without saying, to point out that the amount of benefits and concessions offered, to make foreign direct investments to land here, are at times very substantial, which makes it necessary and essential to study and analyse the effectiveness of such investments. This kind of analysis and study would become a very valuable input for the governments to re-assess, modify and re-structure the policy measures in terms 
of attracting foreign direct investments.

\section{REVIEW OF LITERATURE}

Arindam Baumik and Pradip K. Bhaumik (2006) elaborate that much of the integration of developing countries into the world economy has been caused by relatively high rates of growth of international trade and investment flows, much higher than that of world gross domestic product (GDP). Assef Razin and Efraim Sadka (2007) are of the view that economists tend to favour free flow of capital across national borders, because it allows capital to seek out the highest rate of return. These flows also offer other advantages such as reduced risk faced by investors by allowing them to spread and the global integration of capital markets can contribute to the spread of best practices in corporate governance, accounting standards, legal traditions and also the global mobility of the capital. Theodore H Moran (2001) analyses that earlier economic analysts have viewed that, foreign direct investments take place as part of the parent corporations effort to defend or extend its ability to extract profits from quasi-oligopolistic control over intangible assets, in the face of ongoing competitive challenges at home and abroad. The product cycle model emerged in the midst of the fertile burst of insight that tried to make sense of what seemed to be anomalies in multinational corporate behavior. According to Nagesh Kumar and Jaya Prakash Pradhan (2005) in the neoclassical model, growth results from technological progress, growth of labour force both of which are treated as exogenous and capital accumulation that is subject to diminishing returns. However, new growth theories incorporate the role of knowledge or technology endogenously as a factor of production in its own right, and provide the possibility of non-diminishing return to capital. The recognition of the role of knowledge in economic growth has also lead to a renewed interest in the analysis of the role of FDI in growth. De J Gregorio (2003) analysed the role of FDI in economic growth, and discussed whether, based on these results, there was some rationale for special policies that discriminate in favour of particular sectors to attract FDI and promote growth at a sectoral level

\section{OBJECTIVES}

- To assess the FDI inflows in India as well as the state of Tamil Nadu

- To study the impact of FDI inflows in India and Tamil Nadu on the Economic Growth.

\section{RESEARCH METHODOLOGY}

This study is a modest attempt to identify the impact of FDI (Foreign Direct Investment) on economic growth in India with special reference to Tamil Nadu State based on data available from secondary sources such as Statistical Handbook, RBI Bulletin, etc. The period of study is ten years from 2008-09 to 2018-19. The data collected for the research study are entirely the secondary data published by both the state and central governments. The foreign direct investment inflow data were obtained from the publications of the Directorate of Industrial Policy and Promotion, Government of India. Similarly the FDI flow year wise data are from the periodically up dated publications of the Directorate of Industrial Policy and Promotion, Government of India's website which is the only authentic source of information for these statistics. The collected data are subjected to various statistical techniques such as descriptive statistics (Mean, Standard Deviation, Coefficient of Variation), Compounded Annualized Growth Rate (CAGR), Linear Growth Rate (LGR) and Regression Analysis.

\section{ANALYSED RESULTS}

\section{VI.1. Trend in FDI Inflow: Tamil Nadu and India}

Table 1 is portrayed with results of trend and growth analysis for FDI in Tamil Nadu and also in national level. As portrayed in the table, FDI in Tamil Nadu, Rs.7757 crore in 2008-09 has shown a declining trend in 2009-10. Between 2009-10 and 2012-13, it exhibited an upward trend and in the year 2013-14 again it declined to 12595 crore. In 2014- 15, it jumped to Rs.23361 crore from Rs.12595 crore in 2013-14 and in 2015-16 again it showed an upward trend and in the next year 2016-17 it fell down 14830 crore .In 2017-18 it again rose upto 22354 crore and it the year 2018-19 it was positioned at 18164 crore. Over the period 10 years under study, the FDI in Tamil Nadu had significant growth rate of 8.02 per cent when compounded annually. The FDI in India has also shown a significant positive growth at compound rate of 3.98 but with crisscross trend. Further, FDI in India was less volatile compared to that of Tamil Nadu (CV $=56.71$ for Tamil Nadu compared to 24.24 for India). 
(Rs. in crore)

Table 1: FDI IN TAMIL NADU AND INDIA

\begin{tabular}{|l|l|l|l|}
\hline Year & FDI in Tamil Nadu & FDI in India & Gross NPA Ratio \\
& (Rs. in crore) & (Rs. in crore) & $(\%)$ \\
\hline $2008-09$ & 7757 & 41873 & 18.5 \\
$2009-10$ & 3653 & 37745 & 9.7 \\
$2010-11$ & 6115 & 34647 & 17.6 \\
$2012-13$ & 6711 & 45556 & 14.7 \\
$2013-14$ & 12595 & 34298 & 44.5 \\
$2014-15$ & 23361 & 36046 & 34.9 \\
$2015-16$ & 29781 & 45148 & 51.7 \\
$2016-17$ & 14830 & 55457 & 53.7 \\
$2017-18$ & 22354 & 60220 & 24.6 \\
$2018-19$ & 18164 & 60974 & 36.6 \\
\hline Mean & 14597.55 & 64375 & 28.2 \\
SD & 8279.11 & 46939.91 & 30.55 \\
CV & 56.71 & 11378.91 & 15.062 \\
CAGR & 8.02 & 24.24 & 49.54 \\
\hline
\end{tabular}

Figure 1:FDI inflows in India and Tamil Nadu

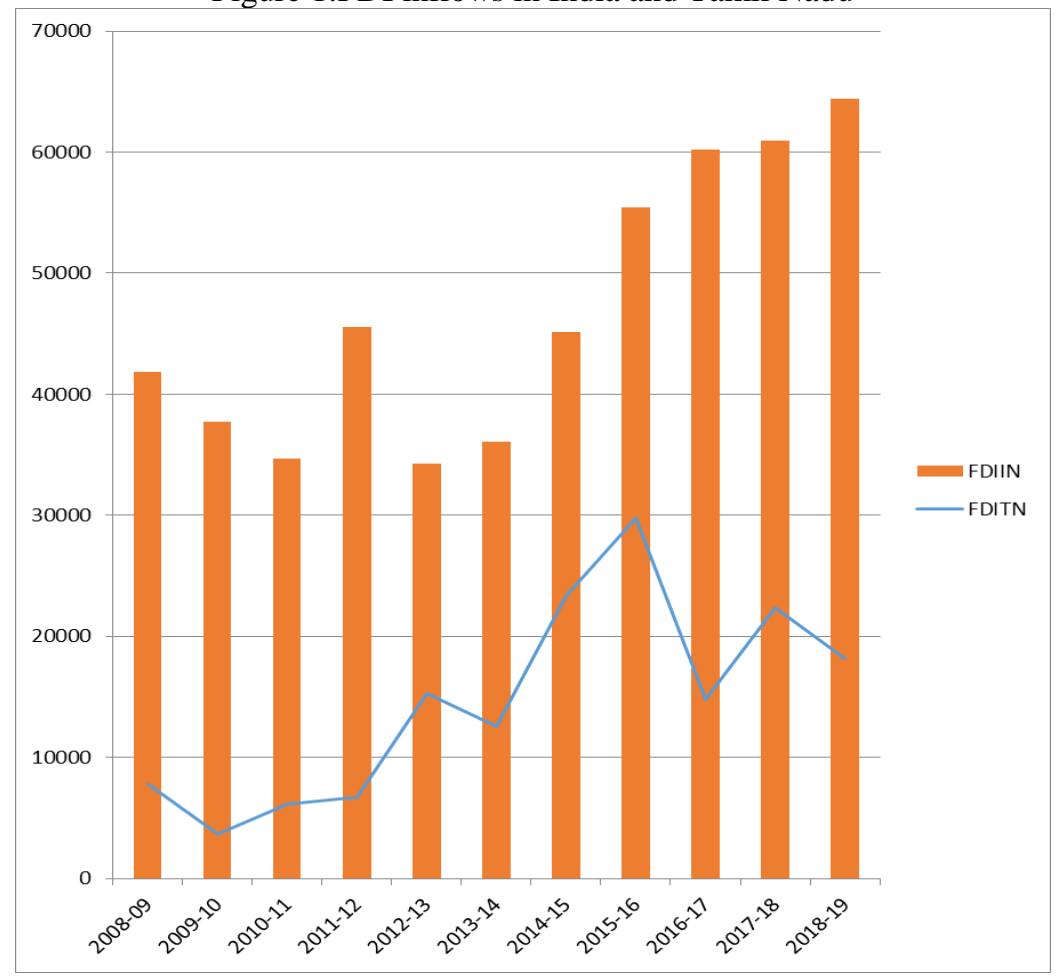

\section{VI.2. Trend in National Income}

The status of Gross and Net National Income is explored by trend and growth analysis of relevant data for 10 years from 2008-09 and 2018-19, and the results of the analysis are given in Table 2. As given in the table, the Gross National Income,
Rs. 11482091.36 lakhs on the average, exhibited a continuous increase throughout the period of study at significant compounded rate of 11.65 per cent per annum and reached at Rs. 18816538 lakh in 2018- 19 
from Rs. 5597140 lakh in 2008-09.

The trend and growth in Net National Income are also positive and significant. The Net National Income, Rs. 10276922.36 lakh on the average, has kept increasing every year significantly at CAGR of 11.60 per cent. The trend and growth in per capita net national income at current prices is also similar to that of total Gross and Net National Income.
The Per Capita Net National Income, Rs.43604 in 2008-09, have grown significantly at the rate of 10.15 per cent when compounded annually. Hence, it is evident that there has been a significant uptrend and positive growth in Gross National Income, Net National Income and Per Capita Net National Income in India during the period.

Table 2:GROSS AND NET NATIONAL INCOME

\begin{tabular}{|c|c|c|c|}
\hline Year & $\begin{array}{l}\text { Gross National } \\
\text { Income } \\
\text { (Rs.Lakhs) }\end{array}$ & $\begin{array}{l}\text { Net National } \\
\text { Income } \\
\text { (Rs.Lakhs) }\end{array}$ & $\begin{array}{l}\text { Per Capita Net } \\
\text { National Income } \\
\text { (Rs) }\end{array}$ \\
\hline 2008-09 & 5597140 & 5031943 & 43604 \\
\hline $2009-10$ & 6439827 & 5780028 & 49402 \\
\hline 2010-11 & 7702308 & 6942089 & 58534 \\
\hline 2011-12 & 8932892 & 8052996 & 66997 \\
\hline $2012-13$ & 9834581 & 8774615 & 71050 \\
\hline 2013-14 & 11132877 & 9934405 & 79412 \\
\hline 2014-15 & 12340772 & 11007592 & 86879 \\
\hline $2015-16$ & 13409892 & 11961524 & 93231 \\
\hline 2016-17 & 15185986 & 13595261 & 104659 \\
\hline $2017-18$ & 16910192 & 15128474 & 114958 \\
\hline 2018-19 & 18816538 & 16837219 & 126406 \\
\hline Mean & 11482091.36 & 10276922.36 & 81375.64 \\
\hline $\mathrm{SD}$ & 4302435.03 & 3835769.18 & 26751.50 \\
\hline $\mathrm{CV}$ & 37.47 & 37.42 & 32.87 \\
\hline CAGR & 11.65 & 11.60 & 10.15 \\
\hline
\end{tabular}

Figure 2:Gross and Net National Income along with Per Capita Net National Income in India from 2000-01 to 2018-19 


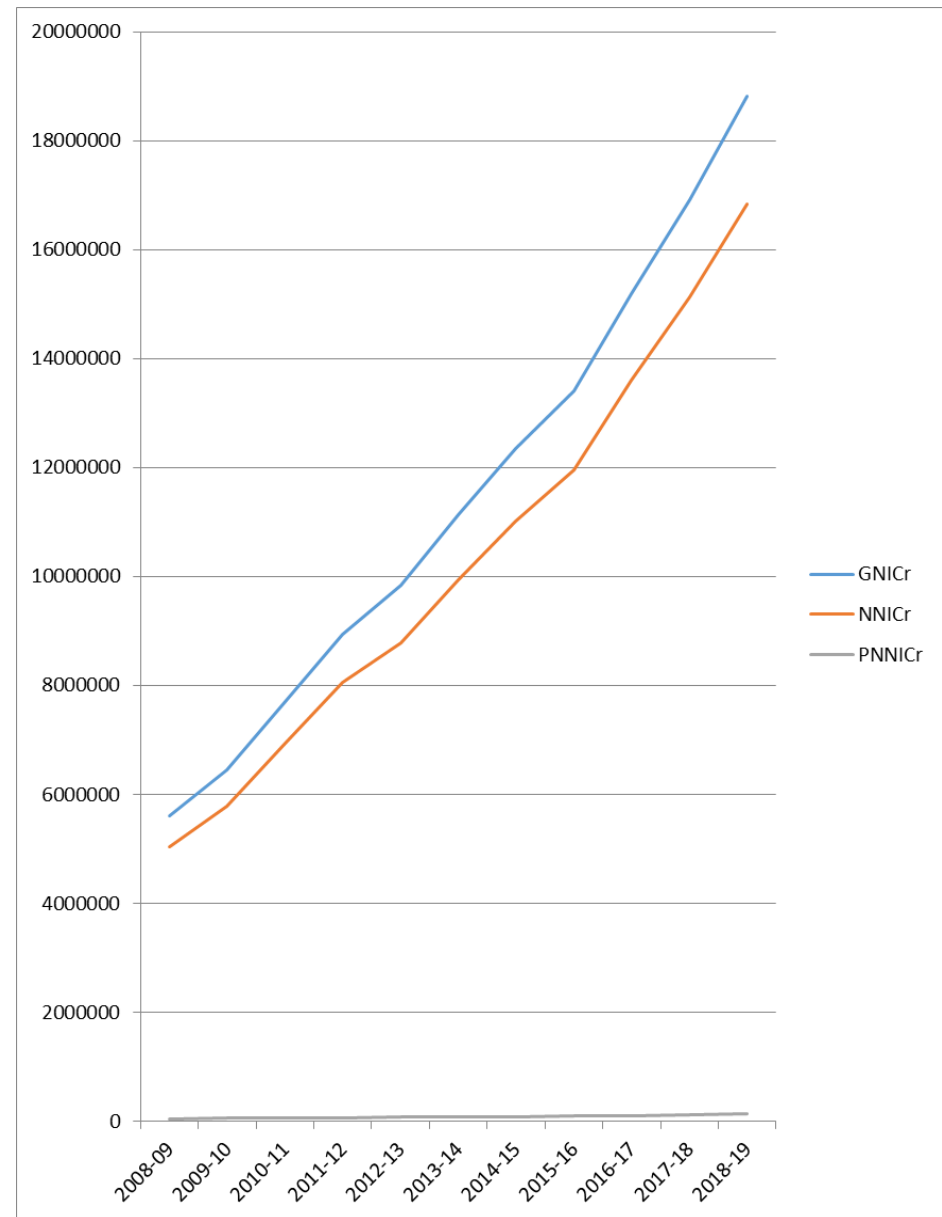

\section{3. Impact of FDI}

The regression analysis is applied to test the impact of FDI on various economic growth variables using the following model.

$$
\begin{aligned}
& \text { GROWTH }=\mathrm{F}(\text { FDI_TN }) \\
& \text { i.e., GROWTH }=\alpha+\beta 1 \text { FDI_TN }+\mu
\end{aligned}
$$

The above model is extended to include overall National level FDI (FDI in India) as confounding variable along with FDI in Tamil Nadu in order to ascertain whether overall FDI inflow to the country also affect the economic growth of the State (Tamil Nadu). So, the extended model is:

$$
\text { i.e., GROWTH }=\alpha+\beta 1 \text { FDI_TN }+\beta 2 \text { FDI_IND }+\mu
$$

Where,

$$
\begin{aligned}
& \text { GROWTH }=\text { Growth Variables } \\
& \text { FDI_TN }=\text { FDI in Tamil Nadu } \\
& \text { FDI_IND = FDI in India }
\end{aligned}
$$

$\alpha=$ constant term

$\beta 1$ and $\beta 2=$ estimated coefficients $\mu=$ error term
Table 3 is depicted with the results of the regression analysis identifying the impact of FDI inflow in Tamil Nadu and India on GNI, NNI and PCNNI at constant prices. As depicted in the table, all the regression models between GNI and FDI, NNI and FDI and PCNNI at constant prices and FDI are fitted significantly. However, the explained variance of the models for FDI inflows in India with GNI, NNI and PCNNI is less compared to the models for FDI inflows in Tamil Nadu with all three National income variables. That is, R2 values of the models regressing national level FDI with GNI, NNI and PCNNI at constant prices are $0.62,0.63$ and 0.64 compared to the R2 values of $0.64,0.58$ and 0.54 of the models regressing FDI inflow in Tamil Nadu with those national income variables respectively. Further, there is no notable improvement in the explained variance of the models with inclusion of national level FDI along with FDI inflow in Tamil Nadu.

The coefficient of FDI inflow in India is not different from zero (insignificant) in the first two extended models (regression models with both FDI variables as predictors and GNI and NNI as dependent variables). But for the third model The PCNNI tend to increase significantly by 0.303 per cent for every 1 per cent increase in FDI inflow in Tamil Nadu whereas the rate of increase in PCNNI is marginally higher 0.38 against same amount of increase in FDI inflow in India.

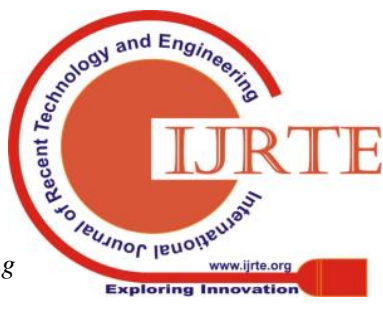


TABLE 3: REGRESSION ANALYSIS OF FDI INFLOWS ON ECONOMIC GROWTH

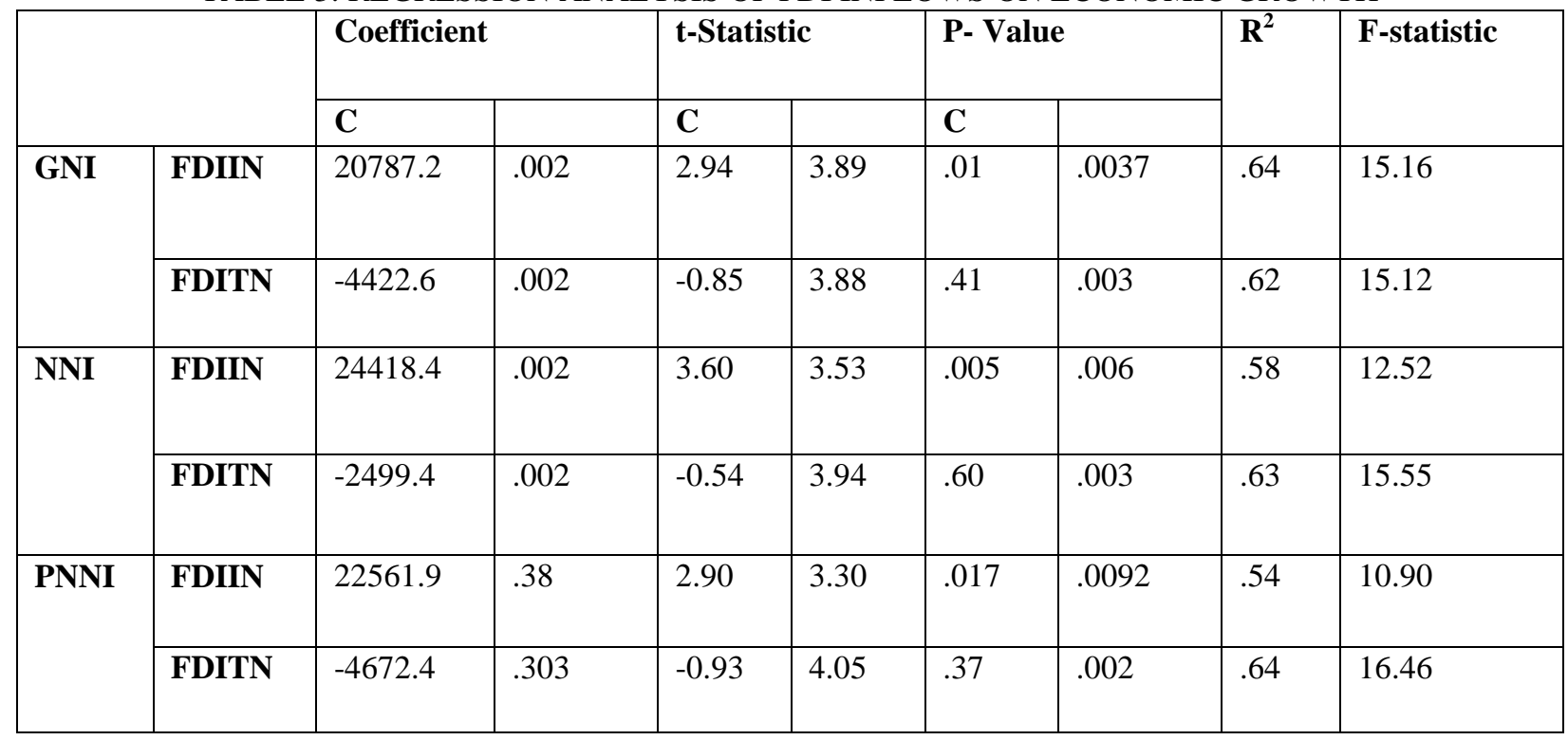

\section{CONCLUSION}

Foreign direct investments in India have been playing a pivotal role in shaping and strengthening the Indian economy as it was the need of the hour for India to get investment as well as the state of the art technology. Government of India took extra effort to attract investments from overseas and that required continuous modification of the regulating framework. This study, having analysed the inflow of Foreign Direct investment in to India during the period 2008-09 to 2018-19 has concluded that the FDI inflow in to the nation has been consistent and been growing significantly, as the economy of the country and the dynamic transformation of global economy have demanded. This inflow of foreign direct investments has consistently created a positive impact on the economic indicators, making it an essential factor to be very attentively looked after for a sustained growth.

\section{REFERENCES}

1. Arindham Banik and Pradip K Bhaunik,Foreign Capital Inflows to China, India and the Caribbean ; Trends, Assessments and the Determinants, 2006

2. Assat Razin \& Efraim Sadka, Foreign Direct Investment: Analysis of Aggregate Flows, Princeton University Press 2007.

3. Nicholas A Phelps and Jeremy Alden,Foreign Direct Investment and the Global Economy Corporate and Institutional Dynamics of Global Localisation, The Stationery Office 1999.

4. Theodore H Moran, Parental Supervision: The New Paradigm for Foreign Direct Investment and Development, Institute for International Economics, Washington 2001

5. Nagesh Kumar and Jaya Prakash Predham, Foreign Direct Investment : Externalities and Economic Growth in Developing Countries; Sime Empirical Explorations, Palgrave Macmillan in Association with International Economic Association.

6. De J Gregorio, The Role of Foreign Direct Investment and natural resources in Economic Development, 2003 